\title{
Sino-speak: Chinese Exceptionalism and the Politics of History
}

\section{WILLIAM A. CALLAHAN}

This article examines how recent books by academics and public intellectuals are reshaping the discourse of the rise of China. While earlier trends argued that China was being socialized into the norms of international society, many texts now proclaim that due to its unique civilization, China will follow its own path to modernity. Such books thus look to the past-China's imperial history-for clues to not only China's future, but also the world's future. This discourse, which could be called "Sino-speak," presents an essentialized Chinese civilization that is culturally determined to rule Asia, if not the world. The article notes that nuanced readings of China's historical relations with its East Asian neighbors provide a critical entry into a more sophisticated analysis of popular declarations of "Chinese exceptionalism." But it concludes that this critical analysis is largely overwhelmed by the wave of Sino-speak.

$\mathrm{I}_{\mathrm{r}}^{\mathrm{T}}$

IS COMMONSENSE NOw to say that the world is in the midst of a grand shift of power from the West to the East. Due to its rapid economic growth, large territory and population, modernizing military and glorious civilization, many commentators have concluded that China will not only be the next superpower, but is destined to dominate the twenty-first century. People in China and around the world thus are asking about Beijing's plans for the future: What are China's grand objectives? What will it do with its new power? Will China buck the historical trend of dissatisfied powers to "peacefully rise" within the current international system, as its official policy tells us? How will Beijing reshape international norms and institutions as it shifts from being a rule-taker to a rule-maker?

In the 2000s the trend among scholars was to see China's values converging with Western ones as its economy and society became more integrated into the international system. In Social States: China in International Institutions, 1980_ 2000, for example, Alastair Iain Johnston argues that Beijing has been socialized into international norms through its growing practice of multilateral diplomacy (Johnston 2008). Rosemary Foot and Andrew Walter go even further to argue

William A. Callahan (Callahan@Manchester.ac.uk) is Chair of International Politics and China Studies in the Politics Department of the University of Manchester and Co-Director of the British Inter-university China Centre, Oxford. 
that China is more of a status quo power than the United States — at least during the George W. Bush administration (Foot and Walter 2011). According to this view, the future is located in the West (although maybe not the U.S.), and involves the innovation and distribution of international society's new values and institutions.

While the trend in the 2000s was to look to future convergence between East and West, this Trends essay examines books that look to the past-China's imperial history-not only for China's future but also that of the world. Rather than figure China's modernization as a process of socialization, which they would criticize as "Westernization," books as diverse as Martin Jacques's When China Rules the World (2009), Liu Mingfu's Zhongguo meng [The China Dream] (2010) and David C. Kang's China Rising (2007) each argue that China has its own modernity, which is not only different from the West but is actually its opposite. According to this view, which is promoted by both academics and policy-makers, China is building its own road, following a model of Chinese exceptionalism that promotes global peace and harmony rather than what they see as Pax Americana's incessant wars. While in the 1990s the debate about identity focused on "Chinese nationalism," in the 2000s China's identity politics have gone global, using traditional Chinese ideals to order the world.

By the autumn of 2008, this new approach seemed to be validated by changes on the ground. The combination of the successful Beijing Olympics and the start of the global financial crisis in New York showed that China could be successful on its own terms, especially in comparison with America. Hence while 1990s nationalist pot-boilers like China Can Say No declared that "China does not want to lead any country, and only wants to lead itself” (He 1996, 3), now Chinese elites are saying "yes" to calls for Beijing to lead the globe. ${ }^{1}$

But writing about the present, let alone predicting the future, is a risky business. Since these books were published things have changed again. By 2009, Beijing's foreign policy had become much more assertive, with China aggressively pushing its own core interests and values on the world stage in a less than charming manner. China's futurologists, however, remain undaunted; they address this problem of constant and unpredictable change in a particular way: to understand the future, they look to long-term trends from the past. The other three books examined in this Trends essay-Yuan-Kang Wang's Harmony and War (2011), Charles Horner's Rising China and Its Postmodern Fate (2009) and Anthony Reid and Yangwen Zheng's edited volume, Negotiating Asymmetry (2010) — take a more sober view of China’s “peaceful rise." Yet they, likewise, look to history to argue their points.

So history is everywhere-but as we will see, these six books take radically different approaches to historiography: some search for how China's true

\footnotetext{
${ }^{1}$ For a discussion of the geopolitics of Chinese nationalism see Hughes 2011.
} 
history determines its past-present-future, while others see history as a toolbox of precedents, concepts, and advice for the challenges that the People's Republic of China (PRC) faces today. Rather than explore China's history of the future in terms of optimists versus pessimists, this essay considers how pairs of books from three different institutional contexts debate China's future: Martin Jacques's When China Rules the World and Liu Mingfu's The China Dream exemplify public intellectual discourse; David Kang's Rising China and Yuan-Kang Wang's Harmony and War show the contours of historiographical debates in international relations literature; and Charles Horner's Rising China and Its Postmodern Fate and Anthony Reid and Yangwen Zheng's Negotiating Asymmetry demonstrate how historians are complicating popular views of China's future.

To make sense of these different approaches to history and to China, this essay examines how authors employ a set of distinctions - convergence/divergence, East/West, tradition/modernity, civil/military and inside/outside-to make sense of China's future and the world's future. Theoretically, these books move from asserting the coherent master narrative of "China in/and/is the world" to interpreting more detailed and disjunctive regional explanations. In this way we move from singular understandings of China's destiny to multiple understandings of China's role in the world. The conclusion considers the growing influence of the discourse of "Chinese exceptionalism" by comparing it with the celebrations of the rise of other Asian giants like Japan and the Pacific Rim in the late twentieth century. While the essentialist view of China promoted in the books of Martin, Liu, and Kang is inconsequential to academic debates, their new orientalist discourse, which I call "Sino-speak," is important because it is very popular among opinion-makers and policy-makers in China, Europe and the U.S. The conclusion thus outlines the contours of Sino-speak's Chinese exceptionalism to argue that the use and abuse of history is more than an academic issue: it informs how elites in China and the West are shaping the future world order.

This mix of scholarship and policy-making is part of a broader trend in China and the West, where policy-makers employ academic sources and academics appeal to populist audiences as public intellectuals. While it is impossible to cover such a large topic in a single Trends essay, my goal here is to probe how Chinese elites are thinking about their future in terms of their past.

\section{The New Orientalists: Martin Jaceues and Liu Mingfu}

For the past decade, many authors have been busy charting the rise of China to superpower status. As the title When China Rules the World: The End of the Western World and the Birth of a New Global Order attests, Martin Jacques has even greater ambitions. This 550 page epic, which was written for a wide readership including opinion- and policy-makers, aims to expand our horizons to show 
how China's rise will reshape the world economically, politically and culturally. China, Jacques tells us again and again, is not a "copy" that "ape[s] the West" (9). It is unique and thus needs to be understood on its own terms. After providing a revisionist history of the West's imperial hegemony, he deconstructs the universal ideals of modernity to show how they are products of Europe's (and then the U.S.'s) particular cultural and historical experiences. Jacques then explores the multiple modernities that Eurocentrism has obscured, arguing that we need to appreciate how China's modernity is not only unique, but better.

This is so, Jacques tells us, because China is the only ancient civilization that has an unbroken and intimate link with its past. Due to the enormous weight of this continuous history, convergence with "Western" values is impossible. Because of historical differences, political divergence is the only possible option. Thus, "difference" is the key concept for understanding China; indeed, Jacques concludes his book by explaining China's "Eight Differences" (from the West). He is particularly fascinated by two ideas that directly challenge the conventional political vocabulary: Jacques figures domestic politics in terms of the civilization-state rather than the nation-state, and global politics in terms of China's tributary system rather than the Westphalian international system. Together these ideas describe a hierarchical Sinocentric order both at home and abroad; other states will have to adapt to this new order, starting in Asia and eventually the rest of the world as well.

Although the book has many academic sources and references, ${ }^{2}$ Jacques's understanding of history and tradition is quite thin. History is looted for episodes and ideas that support the "China's rise/the fall of the West" thesis in ways that are remarkably similar to official writings in the PRC. Howard French thus presciently concludes that Jacques is unable "to get beyond China's own official cant. The book often reads like a compilation of ideas gleaned by the water cooler at the Chinese Academy of Social Sciences, the state's official think tank" (2010). On the basis of spotty evidence, Jacques argues that due to its glorious civilization, China is culturally determined to rule Asia, if not the world.

Although Jacques raises the possibility of multiple modernities, he simultaneously limits the range of possibilities available to the PRC because he asserts a singular China. Throughout the book, he stresses "unity" as a key Chinese value. This unity is not simply political, but also ontological and epistemological: there is one China, one Chinese identity, and one proper way to understand China. The book is full of determinist statements of "inevitables" and "inconceivables" that tell us what "China" can—and more importantly cannot—do. Most notably: "it is inconceivable that Chinese politics will come

\footnotetext{
${ }^{2}$ In the interest of full disclosure, I need to note that Jacques quotes my book, Contingent States (Callahan 2004), dozens of times. As this essay will show, however, I have a different understanding of China's past, present and future.
} 
to resemble those of the West" (395). This appeal to a singular China that is the opposite of the liberal democratic West imposes a strict East/West geocultural framework that is reminiscent of Orientalist projects of the past, except in reverse. Curiously, here Jacques follows the example set by Chinese postmodernists and New Leftists whose "patriotic worrying" likewise deconstructs the West in the service of a positivist project to find the correct formula that will save China (Davies 2007, 1); save for the fact that Chinese intellectuals now not only seek to save China, but also see themselves as responsible for saving the rest of the world. Once again, "civilization” justifies imperial politics; this time, China is the central empire.

Jacques discards one grand dichotomy, tradition/modernity, in order to assert another: East/West. He likewise questions neoliberalism's economic determinism (capitalism producing democracy) in order to assert the cultural determinism of China's civilizational destiny. The result is an Eternal China in an essentialized world that is devoid of political choices. To paraphrase Gertrude Stein: China is China is China, is China-get used to it. Jacques therefore does more than argue against "convergence through socialization;" he is actually telling "the West" that it needs to be socialized into the Chinese way: Westernization needs to be replaced by Easternization.

Why should we care? When China Rules the World is not noteworthy because of new sources or nuanced analysis; Jacques cherry-picks amenable facts from secondary sources for a simplistic and partisan reading of China's past and future. The book is important, however, because many world leaders, policy-makers and opinion-makers are influenced by it. ${ }^{3}$ It was translated into Chinese with great fanfare in 2010 and is now popular among Chinese scholars, officials, and leaders because it confirms the view that China's past is the world's future. ${ }^{4}$ Although Jacques proudly displays his left-wing credentials (he edited the British Communist Party's house journal Marxism Today), his arguments actually feed into hawkish notions of power politics on both sides of the Pacific, which see China and the U.S. as destined for conflict. Indeed, Jacques is widely quoted in the next book I will discuss, The China Dream, which is written by a senior colonel in the People's Liberation Army (PLA).

Liu Mingfu's The China Dream: The Great Power Thinking and Strategic Positioning of China in the Post-American Age generated considerable interest both in China and internationally when it was published in 2010 (Li 2010; Cheng 2010b; Buckley 2010; Romana 2010; Saunders 2010). In contrast to Beijing's policies of peaceful rise in a harmonious world, Liu tells us that to guard its economic rise, China needs to have a "military rise" to contest American power.

\footnotetext{
${ }^{3}$ Such supporters are listed on Jacques's website, available at http://www.martinjacques.com.

${ }^{4}$ For a nuanced critique of such historicism, see Xu Jilin's essays that discuss When China Rules the World to argue that China needs to pursue the mainstream values of universal civilization rather than the values of a particularist Chinese model (Xu 2010).
} 
He warns that being an economic superpower like Japan is insufficient; as a trading state, China risks being a "plump lamb" that other military powers might gobble up (Liu 2010, 255). To be a strong nation, Liu argues, a wealthy country needs to convert its economic success into military power. Rather than follow Deng Xiaoping's "peace and development" policy to beat swords into ploughshares, he tells us that China needs to "turn some "money bags' into “ammunition belts"' (Liu 2010, 244).

Yet The China Dream does not see military conflict with the U.S. as inevitable: "China's military rise is not to attack America, but to make sure that China is not attacked by America” (Liu 2010, 263). Liu thus uses deterrence logic to stress that China must seek peace through strength: its peaceful rise to great power status must include a "military rise with Chinese characteristics that is defensive, peaceful, limited, necessary, important and urgent” (263). If the U.S. chooses to accommodate China's rise rather than challenge it, then "China's dream need not be America's nightmare," he assures us (Liu 2010, 263). Rather, the goal of this strategy is "to grasp the strategic opportunity for strengthening the military" in order to surpass America to become the world's number one great power (Liu $2010,25)$.

Why should we pay attention to The China Dream? Liu is a Senior Colonel in the PLA who teaches at China's National Defense University, so his work could reflect the military's views. But since Liu is a political officer who deals with ideology rather than a flag officer who leads troops, many wonder if The China Dream is actually that significant. Although some commentators warn us not to exaggerate Liu's "extreme" views (Saunders 2010), I think that The China Dream is an important part of the conversations about China's geostrategic future taking place in the barracks, on the web, and among public intellectuals. In response to the book, over eighty percent of the netizens polled by Huanqiu shibao (Global Times) agreed that China should pursue global military supremacy. ${ }^{5}$ The Maoist website "Utopia” reported with glee on both this popular support and-more importantly-how foreigners feel threatened by The China Dream (Cheng 2010a). While some military intellectuals see Liu's China dream as a "fantasy," others like the widely-quoted PLA strategist Col. Dai Xu are even more pessimistic about inevitable conflict between China and the U.S (“China's aim" 2010; see also Zhang 2010; Luo 2010; and Hughes 2011). Indeed, compared with the conspiracy theories that characterize much of China's strategic thought, ${ }^{6}$ The China Dream is quite "reasonable"-public intellectuals like Pan Wei, for example, see international relations as a series of anti-China global conspiracies like the "booby-trap of Westernization" (Pan Wei 2011, 62). The point is that Liu's book is discussed as part of the debate

\footnotetext{
${ }^{5}$ The results of a similar poll- "Do you think China will become global military power?"- on the Global Times's English-language website were different: 33.33\% agreed and 55.56\% disagreed.

${ }^{6}$ For a discussion of the limits of strategic thought in China see Rozman 2010.
} 
over the direction of China's future (“Zhengdang shijie” 2010). Therefore we should value The China Dream in the same way as When China Rules the World: it is important because people are talking about it and being influenced by it.

It is not surprising that Jacques and Liu both agree that China will soon rule the world, but they describe China's strengths in very different ways: Jacques looks to China's enduring civilization as the bedrock of its economic, political and cultural power; Liu stresses that a great power is not truly great unless it is based on the hard power of its military. Indeed, Liu sees Confucianism as a problem for China rather than as China's solution for the world. He promotes military over civilian virtues, but in an interesting way, stressing China’s cultural strengths only when they help explain the necessity for China's military power. A great power China that has a strong military will benefit world peace and order, he argues, because China always pursues the "kingly way" (wangdao); America's military power, on the other hand, is always illegitimate because it pursues the "way of the hegemon" (badao) (Liu 2010, 101-36).

Like Jacques, Liu employs history in his arguments for China’s twenty-first century role. While Jacques offers a broad-brush history of Eternal China, Liu trawls dynastic history for "heroic" leaders. He picks three famous emperors for their "innovations in military culture:" Qin Shihuang (259-210 BCE), Han Wudi (156-87 BCE) and Tang Taizong (599-649). Together, these three heroic Chinese leaders teach us that "realizing the great rejuvenation of the Chinese nation requires the rejuvenation of the Chinese nation's martial spirit" (Liu 2010, 245). While many see the Song dynasty (960-1279) as a high point of Chinese civilization, Liu sees it as the source of China's weakness. Its focus on civilian culture led not only to the downfall of the Song; it also weakened China's martial spirit. China's centuries of defeat only ended when its martial spirit was revived by Mao and the Chinese Communist Party (CCP), which led to its victory in the Anti-Japanese War, China’s Civil War, the Korean War, and so on. Liu uses this specific reading of history to address contemporary issues and concludes that China needs a strong military not only to guard China's unity and security, but also to preserve global peace and order.

Like Jacques, Liu repeatedly tells us that China's rise cannot be a "copy" of Western great powers' experience; China’s success thus must be judged according to "Chinese characteristics" and Oriental civilization. Liu argues that we are entering the new "Yellow-Fortune Era" that heralds the rejuvenation of the Chinese nation to its rightful place at the center of global politics (Liu 2010, 75ff). Rather than a security dilemma, geopolitics here is an "identity dilemma" of competing civilizational models; The China Dream here echoes popular arguments for a "China model" of politics, economics and culture (Pan 2009; Shi 2010; Zhao 2009; Wang 2011). But this new orientalism is more than a standard cultural argument. Liu's Yellow-Fortune Era highlights the georacial politics of what could be called "yellow supremacism," stressing that the 
Chinese "race" is the "most excellent race," the "superior race," that is "even better than the white race" (Liu 2010, 22). ${ }^{7}$ The China Dream shares this fascination with global race war with other popular and influential books like Jiang Rong's Wolf Totem (2004).

Jacques's When China Rules the World and Liu's The China Dream thus make an interesting comparison. Both are very enthusiastic about China's future and are written for a broad readership both at home and abroad, but they also are speaking directly to their own "local" audiences. Jacques tells Westerners that they need to understand how China will change the world, while Liu warns his Chinese compatriots that they are not prepared to take advantage of precious strategic opportunities. The main difference between the books is what the authors see as the motivating force behind China's remarkable success: Jacques focuses on civilization while Liu sees the military as the primary factor.

While it is easy to focus on the differences - civilization versus military - it is also important to consider similarities. Indeed, both Jacques and Liu solve the problem of "Westernization" with "Sinicization." Countering claims that China's new power in the developing world is "neocolonial," Jacques suggests that we think of it in "neo-tributary terms" instead (376). Here the problem with "Western imperialism" is not "imperialism" itself, but only its Western variant; the solution is not universal justice, but China's benevolent hierarchical empire. This argument is noteworthy because this new orientalism that figures (Chinese) empire as the solution to the world's problems is increasingly deployed by China's elite foreign policy analysts (see Callahan and Barabantseva 2012). The view of an Eternal China that is inspired as well as limited by its weighty historical tradition informs populist books by conservative commentators in both China and America, most notably, Henry Kissinger's On China (2011) and Yan Xuetong's Ancient Chinese Thought, Modern Chinese Power (2011). It is hard to say what direct influence this discussion has on official foreign policy-making. But because these ideas are widely discussed, they are influencing the informal "foreign policy" of how Chinese and other peoples interact in social, educational and commercial spaces (see Campbell 1998, 68-70).

Perhaps the best way to understand the role of popular books like When China Rules the World and The China Dream is to compare them with the highprofile writings of Samuel Huntington on the clash of civilizations (1993) and Francis Fukuyama on the end of history (1989). The point is not whether these articles (and then books) are intellectually sophisticated (or not), or whether U.S. policy is dictated by them (or not). Rather, these texts are powerful as polemics that define problems in specific ways that actually serve to limit the range of possible solutions. Much like Huntington and Fukuyama in the 1990s,

${ }^{7}$ For a critical analysis of this phenomenon see Nyiri 2006. 
populist writings by people like Jacques and Liu are setting the terms of the debate about international politics in the 2010s which in turn generates a certain range of responses. Even when these responses are critical of the "Chinese exceptionalism" argument, they add to its influence by re-circulating the idea that China's "history" and "civilization" are key topics of debate for international politics (see Katzenstein 2010). In other words, they limit discussions of China's future-and the world's future-to conservative arguments about the details of China's past.

\section{China and International Relations Theory: Kang and Wang}

While Liu's and Jacques's books are directed at broad commercial markets, David Kang's China Rising: Peace, Power and Order in East Asia (2007) and Yuan-Kang Wang's Harmony and War: Confucian Culture and Chinese Power Politics (2011) are scholarly books that frame their analysis of East Asian politics in terms of international relations (IR) theory. Wang argues that Realist power politics can explain Chinese foreign policy and Kang looks to ideas and interests to question such a realpolitick view. They parallel the civil/military arguments discussed above: Kang looks to broad civilizational politics while Wang writes a detailed military history. Again, although their conclusions could not be more different, both go to history for answers about the likely character of China's rise in the twenty-first century. In this way, they give an academic spin to new orientalist themes.

Kang was provoked to write China Rising by Aaron L. Friedberg's argument in the early 1990s that "Europe's past will be Asia’s future" (Friedberg1993/94), or, in other words, that East Asian countries are destined to form alliances to balance the growing power of a rising China. When this did not happen (at least until 2009), Kang felt that there was a fundamental problem with Friedberg's question: "I wondered why we should use Europe's past-rather than Asia's own past-to explore Asia’s future" (Kang 2007, xi). After studying East Asian history, Kang came up with startling conclusions: between 1300 and 1900 East Asia was remarkably stable and peaceful, especially in comparison with a very bellicose Europe. The problem, Kang tells us, is conceptual: mainstream IR theory, which is Eurocentric and based on threats and fear, cannot explain East Asia's history of peace and order. Against the Westphalian international system of sovereign nation-states, which is formally egalitarian but informally hierarchic, Kang proposes an East Asian interstate system that is formally hierarchic and informally egalitarian.

In China Rising, and again in East Asia Before the West: Five Centuries of Trade and Tribute (2010) that was written to "complement" the 2007 book, Kang offers a broad-brush history of China's tributary system to argue that the Sinocentric East Asian system was stable for six centuries thanks to a combination 
of interests and identity. In this geocultural system, what is good for China is good for East Asia: "Historically, it has been Chinese weakness that led to chaos in East Asia. When China is strong and stable, order has been preserved" (Kang 2007, 201). Kang thus concludes that in the twenty-first century East Asian nations are not balancing against China due to memories of Beijing as a benevolent hegemon: "East Asian states view China's reemergence as the gravitational center of East Asia as natural" (Kang 2007, 4).

Since this argument is now very popular (and quoted by Jacques, whom Kang then quotes in East Asia Before the West), it is important to remember how radical it was when Kang first formulated it in 2003. It challenges the "default proposition" (Kang 2010, 4) of international relations: the Realist theory of power politics that says that states naturally seek to maximize their security in competition with other states in the anarchical Westphalian system of equal and sovereign nation-states. Even so, a re-reading of China Rising reveals important weaknesses. Simply put, Kang replaces Eurocentrism with Sinocentrism in now familiar ways. While at times he argues against essential identities, Kang's main argument employs a romanticized view of China's imperial past to formulate not just an Eternal China (like Jacques), but an Eternal East Asia where identity, interests, beliefs and borders did not change for six centuries. To maintain this stable order, however, Kang has to exclude key factors from his analysis. While the Mongols were China's primary security challenge, he excludes them from his East Asian interstate system because as nomads, he tells us, they lacked a proper state. Kang is thereby able to ignore one of the most violent acts of the eighteenth century: the Qing state's "extermination" of the Zunghar Mongols as it pacified its Central Eurasian frontier. East Asia Before the West goes even further to argue that it is good policy to attack "barbarian" nomads when they do not properly assimilate to Chinese civilization (Kang 2010, 149, 153). Once again, the Chinese way is the only way: while "western" IR theory needs to recognize China's alternative civilization, China does not need to recognize alternative societies that question its world order.

For the twenty-first century, Kang likewise erases a key factor when he concludes that nationalism is not an important part of China's national identity. He thus employs a variant of new orientalism to argue that China and its hierarchical interstate system are remarkably peaceful. Yet Kang's central thesis has been proven false: since 2009, Southeast and East Asian countries are actually balancing China's growing power by, among other things, strengthening their military ties with the U.S. But rather take this challenge seriously, East Asia Before the West offers an even more simplistic view of Chinese exceptionalism.

Kang's theoretical arguments have problems as well. On the one hand, he tells us that China's commitment to equal sovereignty reassures its neighbors. On the other hand, Kang explains that East Asian nations are happy to be subordinate in a Sinocentric hierarchy. Kang tries to resolve this equality/hierarchy contradiction by declaring that we need to be theoretically eclectic to appreciate 
how Beijing combines such contradictory factors. But he does not clearly outline how this eclecticism works. One could easily argue the opposite: because of their commitment to equal sovereignty, East Asian nations are unlikely to happily submit to a Sinocentric hierarchy. Kang's eclecticism is epistemological as well; he chastises critics for not pursuing East Asia's "true history" while also telling us to be open to new perspectives on the past. This mixture of high positivism and post-positivist interpretation muddies one of the key debates in IR theory and social science methodology. In other words, rather than rely on "eclecticism" to paper over his theoretical problems, Kang needs to take sides to make a convincing argument.

Yuan-Kang Wang, in contrast, is very clear about his theoretical objectivesperhaps too clear. By comparing Confucian Pacificist and Structural Realist explanations of China's national security policy, he directly attacks Beijing's official view of a naturally peaceful China that, as Kang's and Jacques's books attest, is now also popular in the West. While Kang and Jacques look to China's exceptional civilization to explain why East Asian international relations are characteristically peaceful, Wang argues that the power politics of the region's anarchical international system more fully explain patterns of war and peace in East Asia. Indeed, while Kang and Jacques contend that a strong China fosters a peaceful environment, Wang argues that a strong China, like any strong state, will expand, while a weak China will accommodate other powers. Wang's point is not that China has a militarist culture (like in The China Dream), but that cultural factors are largely irrelevant. Wang thus concludes that "Chinese exceptionalism is overstated" (Wang, Y-K, 2011, 184).

Yet in another way, Wang's method is similar to that of Jacques, Liu and Kang: to understand China's present and future as the product of the country's unbroken history. But which history? While many look to a peaceful past, Wang charts a history of violence and conflict. Through a detailed and robust analysis of debates about war and peace in the Song (960-1279) and Ming (1368-1644) dynasties, selected because they embody "pure" Han Chinese values, Wang shows that although Confucianism was the hegemonic ideology, in practice, power politics regulated China's interaction with its neighbors. While others (including Jacques and Kang) point to Ming dynasty admiral Zheng He's voyages as evidence of China's peaceful intentions, Wang argues that these maritime adventures are evidence of how states expand when they are strong. The tributary system is not a zone of hierarchical peace, but evidence of imperial expansion under the threat of violence. In this system, countries like the Zunghar Khanate that refused to accept Chinese supremacy "were defined as inhuman, therefore deserving extermination” (Wang, Y-K, 2011, 149). China does not have an exceptionally peaceful history or civilization; its imperial actions show that it behaves like other great powers.

Wang's close reading of Chinese history offers a powerful rebuttal to the idea that China is naturally peaceful. But convergence to him does not mean China's 
socialization into international society; to Wang, China has always been an active example of the universals of power politics. He uses history to make the ahistorical argument that China is an example of how all states behave essentially the same, rather than an example of an essentially different culture. Wang's new orientalism involves a search for the pure way in which Han Chinese interact with the world as opposed to the impurities of Manchu and Mongol rule.

Curiously, Wang never explains his title Harmony and War; surely he means Confucian harmony or Realist war. But are war and harmony really opposites? What about militant Confucianism or China's martial culture? Do we have to choose between the divergence of culturally deterministic Confucian Pacificism and the convergence of the universal laws of Structural Realism? While Wang's evidence is clear and his theoretical arguments robust, Harmony and War exemplifies the contingencies of interpretation. He tells a good story, but his appeal to "the facts" leaves little room for him to engage with other interpretations of his "data." As the other books show, it easy to use the same historical episode to come to the opposite conclusion. We therefore need to do what Kang was unwilling to do, move from a search for positivist facts to post-positivism's messy practice of interpretation. Only then can we see how identity and security (and civil and military) inform each other in a contingent dynamic that encourages us to question singular views of Confucian pacifism, Realist power politics, and the new orientalism.

\section{Multiple Histories, Multiple Chinas: Horner, Reid and Zheng}

Wang dismisses Confucian Pacificism as a "myth" (Wang, Y-K 2011, 182). In his positivist world, this means it is false. In Mythologies, however, Roland Barthes shows how myths are important beyond any true/false calculus. Myths are the stories that we tell ourselves about ourselves, which "transform history into nature" (Barthes 1972, 129). They produce truths (but not the Truth) in an interpretive logic that figures situations, problems and solutions in particular ways. The objective here changes from searching for the Truth about China's rise to see how Chinese elites are thinking about their future in terms of the past.

This is where Charles Horner's Rising China and Its Postmodern Fate: Memories of Empire in a New Global Context is interesting because it explores how Chinese voices are using history to think about contemporary problems and solutions. While Jacques, Kang and Wang insist that we choose between harmony and war, Horner shows how the civil (wen) and the military (wu) are integrated in dynamic tension. As Joanna Waley-Cohen's work on Qing military culture shows, it is important to understand the civil and the military as complementary discourses; a sophisticated person had to balance civilization and martial valuesall in the service of an expansive imperial project (Waley-Cohen 2006, 8). Indeed, Liu's The China Dream takes on a more nuanced meaning if we see it as the PLA's preferred re-balancing of civil-military relations. 
Like the other books, Horner's Rising China and Its Postmodern Fate looks to history to understand China's future. But while Jacques's and Kang’s Eternal China displays a unique Tradition that feels the weight of its History, Horner looks to many different Chinas as they interact with various world systems. Rather than taking a narrow view of strategy, he sees the combination of the civil and the military as an "intellectually creative activity" that appeals to the "strategic imagination" of history, literature, art, architecture and urban planning (Horner 2009, 145, 2). Rather than define the future in singular terms, Horner charts the complexities of China's (or Chinas'?) many hopes, dreams, anxieties, and ambivalences.

Consequently, Horner's approach differs from Kang’s quest to find "East Asia before the West" because it deliberately places China within a global history. Horner can in this way examine the tensions between memory and modernity as China interacts with the world (something that Wang Hui [2011] does as well, although he comes to different conclusions). The goal is to examine historiography as a set of Chinese mythologies: “To re-examine great eras in China's past is to inspire speculation about how those imperial memories could inform China's national politics and Grand Strategy today" (Horner 2009,145). Horner explores, for example, how strategists now look to the Yuan and Ming experiences of building blue-water navies for arguments about how to accomplish this feat in the twenty-first century. History no longer weighs down on China's leaders and intellectuals; history is flexible, offering a toolbox of models and counter-models about how to make China great-again.

Most interestingly, Horner points to the Yuan and Qing dynasties as examples of China's rich experience in world systems that were not of its own making. Han China was not at the center of the Yuan and Qing dynasties; it was merely one of the component parts of these multi-ethnic empires. Horner argues that Han Chinese did well in them-perhaps better than in the nativist Ming dynasty. Thus, it would be a mistake to think that China's current search for greatness is limited to precedents and models from its own inward-looking history. As we saw in Liu's The China Dream, many Chinese strategists also look to the rise of Europe and America for ideas about building a blue-water navy, creating an Asian Monroe Doctrine, and becoming a successful rising power. ${ }^{8}$

This reframing expands the range of possibilities for a Beijing currently seeking success in an American-led international system: should China's grand objective be to surpass the U.S. within the existing system, or should Beijing create a new and different global regime? Unlike the other authors, Horner does not seek to answer this question except to emphasize how configuring China as a unique, different and separate entity is a mistake. China is part of a global history and this is neither new nor strange: "Whatever China becomes

${ }^{8}$ For a discussion of how China's public intellectuals integrate "foreign" ideas into their polemics, see Creek 2006. 
in the next decades, the country's story will not unfold in isolation. . . Instead China, too, will be an ever-changing product of the meeting of memory and modernity, a part of the world's saga of suffering and glory from which every great nation must now create its future" (Horner 2009, 191).

While Horner provides a corrective for unbalanced views of China that stress either civil or military factors, editors Anthony Reid and Yangwen Zheng and contributors to Negotiating Asymmetry: China's Place in Asia (2010) help us balance views from inside China with views from Asian sources outside of China. By doing so, they problematize the simplistic East versus West geopolitical understanding of new orientalism, and encourage us to question both Sinocentric and Eurocentric views of the world. While Jacques, Liu, Kang, and Wang argue over the high politics of imperial China, Negotiating Asymmetry's writers examine the recent history of Sinocentrism, particularly in the nineteenth and twentieth centuries when China shifted from being an empire to a nation-state. They offer a history of the present as China is currently in the midst of another transition from nation-state to something else: civilization-state, military-state, or empire-state.

Like Yuan-kang Wang, the authors of Negotiating Asymmetry are critical of idealized views of “The Chinese World Order." The chapters use the historical evidence of diverse approaches to interstate relations to hammer home the argument that there is no singular Chinese world order, Asian model, or East Asian system. The main contribution of this book, however, is not its critique of the "Chinese World Order" model. Rather, it takes the more modest approach of filling in gaps in the historical record, showing how East Asian states dealt with China during the transition from a Sinocentric hierarchy to a Westphalian system of equal sovereign nation-states. The chapters graphically show how East Asian leaders actively negotiated their asymmetric relations with China. To understand how interstate relations worked, then, it is helpful to unpack the title: Negotiating Asymmetry.

First, "asymmetry": nearly all the chapters show how difficult it was to find the proper vocabulary for China's unequal relations with its neighbors. Reid's and Wang Gungwu's chapters summarize and analyze how the language of friends and family was employed by different actors. As Wang notes, Asian leaders "preferred the softer hierarchy implied in terms like family and friends" to the harder Westphalian language of international law (Wang 2010, 222). While China generally saw itself as the father of this family of nations, other countries were more comfortable talking about sibling relationships. Vietnam and Burma, Reid concludes, would rather live with China as an elder brother than have to deal with a scolding father (Reid 2010,16). The diplomatic discourse of friendship is trickier. It implies equality, but does not state it outright; indeed, friendship means very different things in different languages. The Burmese court, Reid tells us, hoped for "reciprocal friendship" (Reid 2010,16 ). But the experience of the Siamese court is instructive. Thai kings 
repeatedly wrote to the Chinese emperor of their wish to have friendly relations. The Chinese reply was sharp: it complained that such talk of friendship was "impolite" since Siam was merely a vassal. Bangkok was offended by China’s arrogance; but replied that the appeal to friendship was only following Siamese custom (Koizumi 2010, 56).

Although each chapter discusses interstate relations between neighboring countries, none explores the cultural politics of "neighborliness." In this sense, the fascination with friends and family is overplayed and feeds into the new orientalism of a unique Asian way that the authors otherwise resist. Actually, one variant of the Westphalian system specifically looks to an "international society" that includes states as friends, neighbors, and fellow citizens. The "citizen" metaphor is absent from the discussion of East Asian politics, but what would happen if we thought of interstate relations in terms of inter-citizen relations? Perhaps the main point of the friends/family debate is not the relations themselves, but how all sides needed to actively interpret what they meant. A major point of contention for the Siamese court, for example, was how the Chinese court repeatedly (mis)translated its missives of friendship into declarations of submission.

This brings us to the book title's other element, "negotiating." China and its East Asian neighbors had to actively negotiate the meaning of their relations. Most books on pre-modern interstate relations rely on Chinese documents, and thus Beijing's understanding of world order. Negotiating Asymmetry's main contribution is to provide views from the other side: how neighboring states saw China, and the various tactics they used to negotiate peace, trade, and war. Since Chinese sources characteristically assume that China is a benevolent empire, I hope that Negotiating Asymmetry is translated into Chinese and published on the mainland.

While none accepted the tributary system as "natural," Asian leaders' views of China were largely determined by proximity. Countries that shared a land border with China, like Vietnam, had a harder-nosed view of Beijing's diplomacy because it also involved military coercion. However, Southeast Asian states that engaged in maritime trade with China generally saw it as a distant and wealthy empire. A comparison of Junko Koizumi's chapter on Bangkok's relations with China at the end of the tributary system and Maung Aung Myoe’s chapter on Rangoon's postindependence relations with Beijing shows how neighboring countries had to nimbly dance around the Leviathan. Koizumi starts her chapter with a paradox: how could Sino-Thai relations be so close when they had no formal ties for nearly a century after 1854 ? Bangkok sent its final tributary mission to Beijing in 1852. Over the next century China continually requested tribute, and then a treaty. But Bangkok successfully held off China's demands until the outcome of the struggle between Sinocentric and Westphalian orders was clear, using tactics of evasion, avoidance, delay, procrastination, and rationalization. Siam never actually declared the cessation of the tribute system; rather, 
it always had an reasonable excuse for not sending tribute: the monsoon season had already passed, it needed to prepare new ships, it wanted to go through Tianjin rather than Guangzhou, and so on (Koizumi 2010, 51-2).

The issues were much broader than the familiar tribute/trade debate. Siam's main concern was actually demographic: specifically the kingdom's growing ethnic Chinese community, which constituted around half of Bangkok's population by the early twentieth century. This explains why Siam's leaders were not eager for a treaty either-they were concerned that Beijing would demand extraterritoriality for its subjects. Hence Bangkok decided that female education, which was traditionally not supported by public institutions, now was what we would call a "national security issue." It was necessary to educate Thai women so they could influence their Chinese husbands and children, thus countering the Chinese world order's spread of Confucian civilization (Koizumi 2010, 54, 64).

Bangkok used such diverse tactics to evade formal relations without offending China too much. All the while the Siamese court debated the meaning of tribute, underlining how Bangkok and Beijing had different views of their shared relationship. Rather than either clearly accepting or rejecting China's demands for a treaty, the Siamese court decided that what we now call "strategic ambiguity" was in its best interest. And it worked.

When Burma achieved independence from Britain in 1948, it entered a very different sort of world order. But it encountered some of the same problems with China and employed similar tactics. In both premodern and contemporary times, China was the main strategic issue for Burma; Rangoon's diplomacy thus focuses on how to deal with an "ideologically hostile and traditionally chauvinistic China" (Maung 2010, 114). For various reasons, Burma has pursued a resolutely neutralist foreign policy. But this caused tensions with Beijing in the fifties and sixties; Mao wanted to recruit Burma into his global anti-imperialist camp, warning that if they were not friends, then they would be enemies. At times China's challenges were more direct: Chinese Nationalist (GMD) troops crossed into Northern Burma in 1949, and in a separate incident the PLA occupied parts of Burma from 1953-56. But rather than directly challenging China, Rangoon asked the GMD to leave and kept the PLA invasion a secret. China continued to intervene in Burma's affairs until 1985 through its military and economic support for the Burmese Communist Party's insurgency. But again, Rangoon did not make a major issue of China's interference. Burma flexibly employed tactics of politeness, evasion, discretion and delay to avoid getting drawn into either the Cold War or a hot war with China. Like Siam, Burma learned how to live with Beijing's often coercive tactics. But it is clear that they saw them as neither a natural nor a felicitous model of regional international society.

Both Reid and Wang note that China and its neighbors still suffer from a wide perception gap. Southeast Asians are characteristically concerned over Beijing's intentions; this concern deepened in 2010 when Chinese foreign minister Yang Jiechi told them that "China is a big country and other countries are small 
countries, and that's just a fact" (Pomfret 2010). Although Southeast Asian diplomats have shown great skills in arts of evasion and seduction, it is unlikely that such dilatory strategies will work in the twenty-first century's global village of $24 / 7$ communication. Wang and others are thus concerned that China will react with a narrow nationalism that treats Asian neighbors as second-class citizens.

Negotiating Asymmetry is important because it provides multiple outsider views of the Sinocentric order. To return to Reid and Zheng's subtitle, this fascinating book shows that we cannot take "China's place in Asia" for granted. Neighboring countries were not simply submissive "vassals;" they played an active role in shaping East Asian politics. When Beijing was strong, East and Southeast Asian states learned to make the system work for them, but as soon as China's power waned, its neighbors learned how to play with the Westphalian system's new set of norms, while still keeping Beijing at bay. Negotiating Asymmetry helps us to question the naturalness of both the Sinocentric and the Westphalian world orders and encourages us to critique theories that promote cultural destiny or power politics to the exclusion of other ways of understanding international relations. Unfortunately, Negotiating Asymmetry does not draw these conclusions; it is largely up to the reader to put together this puzzle's many pieces.

Together, the books of Horner, and Reid and Zheng offer a different way of thinking about China and its future. These authors' more nuanced approach to history leads them to more modest and more sober conclusions. Rather than making us choose between convergence and divergence, East and West, tradition and modernity, civil and military, inside and outside, they show how a sophisticated understanding of China and its neighbors needs to appreciate how these factors are not mutually exclusive opposites. Since they are joined in tension, our task is to see how the civil and the military, for example, are balanced in each particular context. Here civilization and history do not determine a country's destiny; rather, they are elements in a de-centered discursive toolbox that people can use to construct alternative historical trajectories, for multiple views of Chinas and worlds.

Unfortunately, such creative and careful interpretations are overwhelmed by the epic discussions of the Chinese century, in a discourse that I will call "Sino-speak." At the risk of reifying populist notions of Chinese nationalism as it goes global, it is necessary to briefly outline Sino-speak's emerging discursive economy.

\section{Conclusion}

Sino-speak is the emerging dialect for the new orientalism. As Jacques's, Liu's and Kang's books show, Sino-speak employs a new vocabulary and grammar of naturalized civilization and essentialized identity and to describe-and 
prescribe-China's rejuvenation to greatness. Certainly this is not the first time an Asian power has challenged Western hegemony. In the 1980s conventional wisdom told us that the torch had been passed to Japan and in the 1990s to the Pacific Rim. Today, many criticisms of Chinese power resemble Japanbashing from an earlier era. But Sino-speak's new orientalism, which justifies China's rise to global power, also has much in common with Japan's celebrations of its uniquely superior culture in the 1980s. The discourse of Chinese exceptionalism is hardly unique; as articulations of American exceptionalism show, part of being a great power is celebrating the moral value of your new world order. This is not simply a scholarly debate because Sino-speak is heavily promoted by government officials, state media, and official intellectuals in China. The alternative to Western hegemony here is not a post-hegemonic international society that is more fluid and open, but a different form of hegemony that is centered on the dynamic relationship of civil and military values in China.

The contours of Chinese exceptionalism, new orientalism, and Sino-speak become clearer when they are compared with how Bruce Cumings's "Rimspeak" (1998) produces space, the state, history, race, and values. In the 1980s and 1990s, the discourse of the "Pacific century" and then the "Asian century" talked of the trans-boundary and trans-oceanic economic and social networks that knit together the Pacific rim. Sino-speak, however, is resolutely continental. China's large territory and population and long history make it a gravitational center around which the Asian region naturally orbits. Instead of celebrating cross-border flows, Sino-speak looks to China's eternal civilization to determine social, cultural and territorial borders.

In the 1990s, business writers, anthropologists, and philosophers all declared that Greater China offered a new grammar of socio-economic power that was centered on overseas Chinese socio-economic networks rather than on centralized state control. In Megatrends Asia, John Naisbitt wrote: "It is not China. It is the Chinese network" to explain the grand shift in economic activity from nation-states to transnational networks (Naisbitt 1996, 7). In the early 1990s, $\mathrm{Tu}$ Weiming likewise argued that the "periphery [i.e. the Chinese diaspora] sets the agenda for the center" in Beijing (Tu 1994, 12). With Sino-speak, the state has returned with a vengeance, but in new forms. Sino-speak asserts China as the center of Asia not as a nation-state, but as a civilization-state, a military-state, an empire-state, and a party-state. Naisbitt's latest book China's Megatrends (2010) turns volte-face to praise Beijing's centralized state power as an enterprise-state, and Tu Weiming has moved from Harvard to Beijing. Even Yuan-Kang Wang and Horner, who take a more critical view of Chinese exceptionalism, are still fascinated with what state power can and cannot do.

Rimspeak worked according to a creole-logic that wove together cultures, ideas and concepts from different places (albeit according to a neoliberal grammar) into a network; outsiders, like the celebrated overseas Chinese communities in Southeast Asia, Australia and North America, constituted some of 
this network's main nodes of transmission. Sino-speak, on the other hand, is fascinated by essential identity and pure "race." Jacques criticizes Chinese attitudes about racial superiority even as he promotes China's superior civilization. Liu envisions the Chinese nation as the "yellow race" in competition with the "white race." Liu, Kang, and Wang exclude "impurities" (Mongols, Manchus and Americans) to test the Chinese race’s attitude towards violence. Cosmopolitanism here is no longer a transnational alternative to ethnonationalism, but the means through which China's national culture is transmitted around the world.

Rimspeak's futurology was largely ahistorical; or, for Japan, it was about escaping the historical legacy of its wartime atrocities. Overseas Chinese identity emerges from mobility and flexibility, rather than from the weight of history. Sino-speak, however, is resolutely historical, asserting epic History to explain China's inevitable rise as a rejuvenation, one that returns China to its rightful place at the center of the world. Reading these books gives one the sense of déjà vu. In addition to mirroring Japan’s arguments from the 1980s, Sino-speak raises topics that were very popular in China a century ago: the value of Confucianism, China's proper role in the world, the global race war, and others in this vein. ${ }^{9}$ It is as though some of the writers are building a time machine to take the world back to 1911 (the Republican Revolution) to have a do-over for Chinese modernity, or to 1799 (the death of the Qianlong emperor) to resume the historical narrative of imperial greatness.

While the Asian century looked to Asian values to explain the region's economic growth, Sino-speak takes economic strength for granted and looks to culture to explain war, peace, and world order. It discards the network-based logic of globalization that ties us all together (for better and for worse) in an integrated global political-economy to assert a sharp geopolitical vision of the world instead. For Sino-speak's partisans history works in reverse, with the Sinocentric neo-tributary system now challenging the Westphalian system to rewrite the wrongs of China's Century of National Humiliation (1840-1949). Likewise, the Beijing consensus challenges the Washington consensus and the China model challenges the American dream in a grand civilizational competition. While Rimspeak celebrated the rise of postcolonial nations, here we have a new empire (which cannot be called imperialist): Eurocentrism is replaced by Sinocentrism, Westernization is replaced by Easternization, and American exceptionalism is replaced by Chinese exceptionalism. Other possibilities for China's futureand the world's future-are largely crowded out of these culturally-determined prognostications. Sino-speak thus expresses thoroughly conservative values in familiar ways to argue against equality and anti-imperialism. Indeed, it mobilizes

${ }^{9}$ See Kang Youwei's Datongshu (2005); for an analysis of this period of Chinese intellectual history see Rebecca Karl, Staging the World: Chinese Nationalism at the Turn of the Twentieth Century (2002). 
hard-core activists in both Beijing and Washington to defend their respective national identities, interests, and security against new threats and age-old others.

As this conclusion demonstrates, it is easy to get caught up in the wave of Sino-speak as it overwhelms nuanced notions of identity and politics to establish the new discursive world order of new orientalism.

But what if Sino-speak is wrong? What if China continues to socialize as an even greater supporter of global norms? What if China's inevitable rise stalls? What if Chinese history does not provide a guide to the future? What if China and the world can actually get along in a new cosmopolitan world that promotes equality and social justice both domestically and internationally?

Unfortunately, Sino-speak leaves little space to ask these questions, let alone answer them. New orientalism's mix of scholarship and policy-making is not crafting a post-hegemonic world order; rather, it provides discursive legitimacy for Sinocentric hegemony in the twenty-first century.

\section{Acknowledgements}

For their helpful comments, I thank Elena Barabantseva, Sumalee Bumroongsook, Mary Erbaugh, Richard Curt Kraus, Daniel Lynch, Jeffrey Wasserstrom, and the JAS's anonymous reviewers. This research was supported by a Leverhulme Trust Research Fellowship.

\section{List of References}

Barthes, Roland. 1972. Mythologies. New York: The Noonday Press.

Buckley, Chris. 2010. “China PLA officer urges challenging U.S. dominance.” Reuters, March 1.

Callahan, William A. 2004. Contingent States: Greater China and Transnational Relations. Minneapolis: University of Minnesota Press.

—. and Elena Barabantseva, eds. 2012. China Orders the World: Normative Soft Power and Foreign Policy. Baltimore: Johns Hopkins University Press.

Campbell, David. 1998. Writing Security: United States Foreign Policy and the Politics of Identity. Minneapolis: University of Minnesota Press.

Cheng Gang. 2010a. "Jiefang jun daxiao Liu Mingfu zhuzhang Zhongguo zhengzuo shijie di yi junshi qiangguo" [Liu Mingfu of the PLA emphasizes that China will become the world's number one superpower]. In Wuyouzhixiang [Utopia], March 3. http:// www.wyzxsx.com/Article/Class22/201003/134608.html [accessed 17 July 2011].

. 2010b. "Liu Mingfu dui benbao shuo, Zhongguo zheng dang shijie guanjun he taoguang yanghui bu maodun [Liu Mingfu tells this paper: China struggling to be the world's number one power does not contradict the "lay low" policy]. In Huanqiu shibao (Global Times), March 2. http://world.huanqiu.com/roll/2010-03/ 730751.html [accessed 17 July 2011]. 
"China’s aim of being top military superpower may be a dream." 2010. In Global Times, March 3. http://military.globaltimes.cn/china/2011-04/509490.html [accessed 17 July 2011].

Creeк, Tiмотнy. 2006. "Xu Jilin and the Thought Work of China's Public Intellectuals." In China Quarterly no. 186: 401-20.

Cumings, Bruce. 1998. "Rimspeak; or, The Discourse of the 'Pacific Rim'." In What is in a Rim? Critical Perspectives on the Pacific Rim Idea, $2^{\text {nd }}$ edn., Arif Dirlik, ed., 53-72. Lanham, MD: Rowman \& Littlefield.

Davies, Gloria. 2007. Worrying About China: The Language of Chinese Critical Inquiry. Cambridge: Harvard University Press.

"Do you think China will become global military power?" 2010. Online poll. In Global Times, March 3. http://forum.globaltimes.cn/forum/showthread.php?t=13769 [accessed 17 July 2011].

French, Howard W. 2010. "In Case You Missed Them: Books by Martin Jacques and Yasheng Huang.” In The China Beat, February 1.

Foot, Rosemary and Andrew Walter. 2011. China, the United States, and Global Order. New York: Cambridge University Press.

Funuyama, Francis. 1989. "The End of History" In The National Interest no. 19 (Summer).

Friedberg, Aaron L. 1993/94. "Ripe for Rivalry: Prospects for Peace in a Multipolar Asia." In International Security 18(3) (Winter): 5-33.

He Beilin. 1996. "Qianyan” [Foreword]. In Zhonggou keyi shuo bu [China can say no], Song Qiang, Zhang Zangzang and Qiao Bian. Beijing: Zhonghua gongshang lianhe chubanshe.

Horner, Charles. 2009. Rising China and Its Postmodern Fate: Memories of Empire in a New Global Context. Athens: University of Georgia Press.

Hughes, Christopher R. 2011. "Reclassifying Chinese Nationalism: The Geopolitick Turn.” In Journal of Contemporary China 20(71): 601-20.

Huntington, Samuel P. 1993. “The Clash of Civilizations?” In Foreign Affairs 72(3): 22 49.

Jacques, Martin. 2009. When China Rules the World: The End of the Western World and the Birth of a New Global Order. New York: Penguin.

—. Martin Jacques: Writer \& Columnist. Personal website. http://www.martinjacques. com [accessed 17 July 2011].

Jiang Rong. 2004. Lang tuteng [Wolf Totem]. Wuhan: Changjiang wenyi chubanshe.

Johnston, Alastair IAin. 2008. Social States: China in International Institutions, 1980-2000. Princeton: Princeton University Press.

Kang, David C. 2007. China Rising: Peace, Power and Order in East Asia. New York: Columbia University Press.

—. 2010. East Asia Before the West: Five Centuries of Trade and Tribute. New York: Columbia University Press.

—. 2003. "Getting Asia Wrong: The Need for New Analytical Frameworks." In International Security 27(4): 57-85.

Kang Youwei. 2005. Datong shu [Great Harmony]. Shanghai: Shanghai guji chubanshe.

Karl, Rebecca. 2002. Staging the World: Chinese Nationalism at the Turn of the Twentieth Century. Durham: Duke University Press.

Katzenstein, Peter J., ed. 2010. Civilizations in World Politics: Plural and Pluralistic Perspectives. New York: Routledge.

Kissinger, Henry. 2011. On China. New York: Penguin. 
Koizumi, Junko. 2010. "Between Tribute and Treaty: Sino-Siamese Relations from the Late Nineteenth Century to the Early Twentieth Century." In Negotiating Asymmetry: China's Place in Asia, Anthony Reid and Yangwen Zheng, eds., 47-72. Honolulu: University of Hawaii Press.

Li Yue. 2010. "Liu Mingfu: Zhong-Mei jingzheng shi yi chang tianjingsai” [Liu Mingfu: Sino-US competition is a track and field competition]. In Jingbao, January 23. http:// jb.sznews.com/html/2010-01/23/content_941864.htm [accessed 17 July 2011].

Liu Mingfu. 2010. Zhongguo meng: hou meiguo shidai de daguo siwei zhanlue dingwei [The China Dream: The Great Power Thinking and Strategic Positioning of China in the Post-American Age]. Beijing: Zhongguo youyi chuban gongsi.

Maj. Gen. Luo Yuan. 2010. "Zhongguo yao cheng yiliu qiangguo buxu you shangwu jingshen" [To become first class power China must have martial spirit]. In Huanqiu shibao, December 12.

Maung, Aung Mroe. 2010. "Dealing with the Dragon: The China Factor in Myanmar's Foreign Policy.” In Negotiating Asymmetry: China's Place in Asia, Anthony Reid and Yangwen Zheng, eds., 95-118. Honolulu: University of Hawaii Press.

Naisbitt, John. 1996. Megatrends Asia. London: Nicolas Brealey.

—. and Doris Naisbitt. 2010. China’s Megatrends: 8 Pillars of a New Society. New York: Harper Business.

Nyiri, PAL. 2006. “The Yellow Man’s Burden: Chinese Immigrants on a Civilizing Mission." In China Journal 56: 83-106.

PAN WeI, ed. 2009. Zhongguo moshi - jiedu renmin gongheguo de 60 nian, [The China model: Reading 60 years of the People's Republic]. Beijing: Zhongyang bianshi chubanshe.

. 2011. "Zhongguo weilai 30 nian: Yuanjing yu xianjing" [China 30 years in the future: Vision and booby-trap]. In Zhongguo weilai 30 nian [China: 30 years in the future], Wu Jinglian et al., eds., 54-65. Beijing: Zhongyang bianyi chubanshe.

Pomfret, John. 2010. "U.S. takes a tougher tone with China." In Washington Post, July 30.

Reid, Anthony. 2010. "Introduction: Negotiating Asymmetry: Parents, Brothers, Friends and Enemies." In Negotiating Asymmetry: China’s Place in Asia, Anthony Reid and Yangwen Zheng, eds., 1-25. Honolulu: University of Hawaii Press.

—. and Yangwen Zheng, eds. 2010. Negotiating Asymmetry: China's Place in Asia. Honolulu: University of Hawaii Press.

Romana, Chito. 2010 "Does China Want to Be Top Superpower?" In ABC News, March 2.

Rozman, Gilbert. 2010. Chinese Strategic Thought Toward Asia. New York: Palgrave.

Saunders, Phillip C. 2010. "Will China’s Dream turn into America’s Nightmare?” In China Brief 10(7) (April 1).

Shi Yinhong. 2010. Quanqiuxing de tiaozhan yu Zhongguo: Duoshi zhi qiu yu Zhongguo de zhanlue xuyao [China and global challenges: China's strategic needs in an era of many troubles]. Changsha: Hunan renmin chubanshe.

Tu Weiming, ed. 1994. The Living Tree. Stanford: Stanford University Press.

Xu Jilin. 2010. "Jueqihou de Zhongguo jiang zouxiang hefang: cong Mading Yake de Dang Zhongguo tongzhi shijie tanqi" [Which direction will a post-rise China go?: Discussing Martin Jacques's When China Rules the World]. In Nandu gongzong luntan, May 23. http://www.chinaelections.org/newsinfo.asp?newsid=188285.

Waley-Cohen, Joanna. 2006. The Culture of War in China: Empire and the Military under the Qing Dynasty. New York: I.B. Taurus. 
Wang Gungwu. 2010. "Family and Friends in Changing Asia." In Negotiating Asymmetry: China’s Place in Asia, Anthony Reid and Yangwen Zheng, eds., 214-31. Honolulu: University of Hawaii Press.

Wang Hui. 2011. The Politics of Imagining Asia. Cambridge: Harvard University Press. Wang, Yuan-Kang. 2011. Harmony and War: Confucian Culture and Chinese Power Politics. New York: Columbia University Press.

Yan, Xuetong. 2011. Ancient Chinese Thought, Modern Chinese Power. Princeton: Princeton University Press.

Zhang Wenmu. 2010. Lun Zhongguo haiquan [China's sea power], $2^{\text {nd }}$ ed. Beijing: Haiyang chubanshe.

Zhao Tingyang. 2009. Huai shijie yanjiu [Studies of the bad world]. Beijing: Zhongguo renmin daxue chubanshe.

“Zhengdang shijie 'guanjun guojia,' Zhongguo meng??" [Is striving to become the world's "champion country" the China dream?]. 2010. In Huanqiu wang, March 3. http:// opinion.huanqiu.com/roll/2010-03/732792.html [accessed 17 July 2011]. 